\title{
Digital Society and Multi-Dimensional Man (Repositioning Marcuse's One-Dimensional Man)
}

\author{
A.Z. Chernyak, E. Lemanto \\ RUDN University \\ Miklukho-Maklaya Str., 6 Moscow, Russian Federation, 117198
}

One of the major concerns of the social philosophy is the technological revolution and its impacts on the social systems. Critical views on the systems from the social philosophers depart from the social predicaments of their time. The pivotal critic of Karl Marx in his work of Das Capital, for example, is on poverty caused by the system of capitalism. Capitalism, for him, only produces various social downturns such as slavery, oppressions, exploitations and impoverishment. Herbert Marcuse, meanwhile, pointed at the same problem, but he came from a different point of view from Marx. Marcuse criticized the abundant society. In One Dimensional Man Marcuse rendered a couple of incisive critics on the industrial society. Industrial society, for him, is marked by the abundance and surplus but this society is still oppressed under a new type of slavery, called voluntary slavery. We may briefly say that both philosophers rendered critics on the same matter of the industrial society, but the two stood on the different position. Marx's critic was on the hungry and deficient society, while Marcuse on a satiated, plenteous and surplus society. The aim of this paper is to present of how Marcuse's One-Dimensional Man ends in the digital age.

Keywords: One-Dimensional Man, Multi-dimensional man, Dehumanization, Exploitation, Instrumentalization, Industrial society, Digital society, Capitalism

\section{Article history:}

The article was submitted on 06.08.2019

The article was accepted on 23.12.2019

For citation: Chernyak A.Z., Lemanto E. Digital society and multi-dimensional man (Repositioning Marcuse's One-Dimensional Man). RUDN Journal of Philosophy. 2020; 24 (2): 286-296. DOI: 10.22363/2313-2302-2020-24-2-286-296

\section{Marcuse's One-Dimensional Man}

The $18^{\text {th }}$ century was the industrial age, the zenith of the progress and the advancement of industries in European countries. The development is like a doubleedged sword. On the one hand, the invention and the advancement of the industrial

Chernyak A.Z., Lemanto E., 2019

(c) () This work is licensed under a Creative Commons Attribution 4.0 International License https://creativecommons.org/licenses/by/4.0/ 
machineries help man producing goods on a large scale. But on the other hand, social problem arose. The advancement of the industrial technology coincided with the problem of social inequality between the capitalist class and the working class. Before the social problem, the social sciences are compelled to criticize.

The characteristic of the social philosophy since the time of Karl Marx's Das Capital (published in 1867) is unique. Das Capital was written as a radical criticism against capitalism of the industrial age. Capitalism, for Marx (1818 - 1883), solely bears an unjust social system and produces a wide social gap between the capitalist class and the working class. Capitalism alienates man from their humanity because of its oppressive system. For example in the system of labor, the employers are exploited for the sake of productivity. Marx named it as the greed of surplus-labor. ${ }^{1}$ The discrepancy between the two classes is immensely extreme. The capitalist class is considered as the gorged class. They are the haves and the rich, while the working class as the starveling class. They are unskilled laborers, uneducated and poor. The relation between these two classes is not partnership, but exploitative like in the master-slave relation. The capitalists are the exploiters and the working class the exploited.

Marx's critical philosophy intends to criticize not only capitalism but also modernism. Modernism is defined as an advanced development of human civilization that is distinguished form the ancient time in all aspects such as character, way of living, worldview, actions, or quality of thought, beliefs, expression and technique. He obviously denotes the feebleness of modern rationality. The profound irony of modernism, for Marx, lies in the contradictory of the ideal goal of the project of modernism and its ill-impacts on the social system. This irony afflicts almost on all social systems from culture, religion, education, politic to the economy.

The primary concern of Marx's Das Capital is the defects of the economic system inherent in capitalism. Marx clearly shows the failure of capitalism. Basically the heading goal of industries and its giant machines, for him, is to alleviate human work physically. The machines replace human's physical works, but ironically it is for the sake of productivity and for the benefit of the capitalist class humans - the working class - are treated like robots. That is the same to say that the creation of the industrial machine is not to replace human physical work, but instead leads man to a robotizing process - robotization; the process of turning a human being into a robot. Capitalism is the system that enslaves humans. In the presence of this social downturn Marx longs a classless society. It is a society that is egalitarian.

In the post-Marxist era social philosophy came up with distinctive social criticism. The post-Marxian philosophers generally were standing on the same line with Marx, but their underlying concern was dissimilar form him. Marx's attention was on the hungry working class and the post-Marxian social philosophers were on

\footnotetext{
${ }^{1}$ Karl Marx. Capital: a Critique of Political Economy. Volume I. First Published In German in 1867 and English first edition in 1887. Moscow: Progress Publishers, 2015. P. 164.
} 
the abundant society. It is the same to say that Marx's critical philosophy renders strong criticism on the capitalism because it is exploitative, enslaved and impoverished the unskilled laborers. Some of Marx's social critics are still relevant for the next century that slavery remains, but the rest is irrelevant.

In the post-Marxian period, industrial society was marked by the abundance. Slavery remains existed but was more subtle. In Herbert Marcuse's words it is a smooth slavery. This subtle slavery was designed by the capitalist system that seemed egalitarian, but was actually exploitative and oppressive. The slavery is mantled by the fulfillment on the single aspect of human life that is economy; material needs. That is exactly the core point of Marcuse's analysis. His critical philosophy is on the abundant society. His insightful critic has its own place among the post-Marxist philosophers, particularly among the leading thinkers of the Frankfurt School (the group of philosophers of the Institut für Sozialforschung in Frankfurt, Germany) from Max Horkheimer, Theodor Adorno, Walter Benjamin, Herbert Marcuse to Jurgen Habermas.

This essay notably addresses the ideas of Marcuse. His position in the critical philosophy is noteworthy because of his observant analysis on the hidden defects of capitalism that bears the social injustice. Marcuse sharply unmasked all sorts of camouflage of the capitalist system. It is deceitful and contained of various forms of injustice, oppression and slavery. Many are deluded by the economic fulfillment, but Marcuse does not. He basically dismantled the deceptive components of the capitalist system. That abundant society, for Marcuse, stay remains in the new form of slavery. Public awareness is sedated by the system of capitalism that seems egalitarian, but is actually full of repression.

Marcuse's exhaustive research and analysis are convincingly presented in his two widely read tracts, Eros and Civilization and One-Dimensional Man. In his critics on the industrial society, Marcuse's analysis renounces the Freudian psychoanalytic perspective. Civilization, for Freud, necessarily supposes oppression. In Freudian worldview, society and its culture are formed through the process of human development. In his theory of human development and the theory of Oedipus complex, Freud stressed that a human being grows into an adult through pressures, suppression and through the process of restraint of their sexual desire. The desire of a child to have his own biological mother is suppressed by the presence of a father who is the symbol of the social order (laws, moral values, norms and ethics). ${ }^{2}$

Unlike Freud's psychoanalytic theory, Marcuse precisely observes that human civilization does not have to presuppose oppression. He refuses the presumption that civilization necessarily presupposes oppression. His observation on the capitalist system discovers a new system of suppression. Modern industrial systems and the capitalist system no longer work with oppressive mechanisms like in the ancient capitalism, but the new enslavement works in a very subtle way. Oppression

\footnotetext{
${ }^{2}$ Franz Magnis-Suseno. Dari Mao ke Marcuse. Jakarta: Penerbit PT Gramedia Pustaka Utama, 2013. P. 254.
} 
in modern capitalism actually works with the law of attraction. In Marcuse's words, the suppression in Freudian worldview is replaced by Eros: enticement. ${ }^{3}$

What makes the oppressive system in the ancient capitalism is transformed into enchanting oppression? Marcuse stresses that by fulfilling the economic needs of the working class the capitalist is able to mantle its oppressive system. It could be said that the fulfillment of the economic needs is a fetish blunting the consciousness of the working class to fight against the unjust system. ${ }^{4}$

The dimension unfulfilled in the Marxian society, for Marcuse, is completed in the modern industrial society through the fulfillment of the material needs, even though he realizes that poverty still exists. Indeed, there is a huge transformation from the time of Marx to the time Marcuse. As presented in the previous part that Marxian society is marked by the lacking, while Marcuse's society by the surplus. This surplus society, for Marcuse, is not critical society. They are not aware of the system repressing and exploiting them. The freedom they have is an illusion, because the totalitarian and the exploitative economic system are still imposed on them. We may briefly say that the life of modern industrial society is wholly controlled by the system that benefits the capitalist class.

If Marx longs a society capable rebelling against the exploitative system, Marcuse indeed longs the existence of a society that is aware of the covert exploitation of the capitalism. Why mindful society? The abundant society, for Marcuse, is a complacent society. It is a society that asocial. The fulfillment of material needs leads them to anti-social. It is a nonchalant society to the social issues. They are heedless and senseless of the exploitative and the oppressive system imposed to them. This satiated society accepts any unjust systems charged to them without critically questioning. They no longer are able to sort out the primary needs from secondary needs. The capitalist system creates needs which ultimately serve the economic interests of the capitalists themselves.

Marcuse's One-Dimensional Man is a critic of the totalitarian hegemony of capitalism, as well as criticism of the satiated society or the surplus society. This plenteous society is an apathetical society. They accept the whole system without questioning and resisting the unjust system, unfair policy and discriminative regulation imposed to them. This society is like a total passive society in front of the exploitative system charged to them. This society is unaware and less understanding of the importance of the other dimensions such social, culture, art, spirituality, solidarity, and other, except the material needs.

Placing human being only on that single dimension is a form of dehumanization. It is the same as saying that the oppressive systems imposed to the society place human beings like cattle. The working class is exploited like a flock for the benefits of the capitalists. They are like machines working beyond the human

\footnotetext{
${ }^{3}$ See Herbert Marcuse. Eros and Civilization: A Philosophical Inquiry into Freud, New York: Vintage Books, 1955. P. 185.

${ }^{4}$ See Herbert Marcuse. One-Dimensional Man. Studies in the Ideology of Advanced Industrial Society, London: Routledge \& Kegan, 1964. P. XIII.
} 
capability. The laborers are used like tools for the benefit of the capitalist. The question needed to be discussed here is that how human civilization should be built according to Marcuse? Is it possible to find the exit of the Freudian reality principle - civilization necessarily presupposes oppression? Marcuse believes that the exit is possible through the development and the advancement of technology itself.

\section{Multi-Dimensional Man}

Marcuse's anxiety on the problem of exploitation and oppression inherent in the system of ancient capitalism seems to come to an end in the digital age. His conviction of the possible exit of the Freudian reality principle through the advancement of the technology itself is truly open. Digital technology makes it possible. The expectance of the emergence of society free from exploitation can occur in digital society. There are convincing reasons for saying that that the characteristics of digital technology come in line with philosophical principles of the human development. In the following paragraphs will be presented of the arguments against Freud's theory of reality principle.

The characteristic and the basic principle of digital technology is creativity. This principle goes hand in hand with the principle of the ideal process of human development. Creativity principle is a principle that emphasizes on the process of self-actualization of man. Creativity principle as the characteristic of digital technology and self-actualization principle in human developing process can become the way out of the problem in the Freudian reality principle and of the achievement or performance principle in the ancient capitalism.

In the creativity principle one determines one's own capacity. One has to realize the potentials and capacities he or she has to develop in his or her own way. This is the process of becoming an authentic self. This principle can be defined through Giovanni Pico della Mirandola's humanism of the image of man. According to Pico man is created in the undetermined image. One's image is determined by one's own self. It is the same to say that man basically autonomy. One has freedom to determine one's own self. With that freedom man decides and makes a choice for him/herself. Shortly we may say that man's destiny is on $\mathrm{him} /$ herself. As Pico stated that "we have made you... as the free and proud shaper of your own being, fashion yourself in the form you may prefer."

With that freedom man also makes a choice considered right for his/her destiny. This particular freedom goes in the same line with the characteristic of digital technology. Man has freedom to choose what sort of works fit to his/her capacity and interest. Man are also free to choose and to sort out the systems imposed to them. In the digital era, the partnership-based system gives more opportunities and alternatives to everyone, including choices of having networks.

${ }^{5}$ Giovanni Pico della Mirandola, Oration on the Dignity of Man (translated by A. Robert Caponigri). Washington: Regnery Gateway, 1956. P.7. 
This opportunity can be become an exit of the oppressive systems imposed to the society. We may say that the partnership principle and creativity principle are based on a free will to choose according to one's capacity and interest.

Reality principle and performance principle in the ancient capitalism can only be overcome by the creativity principle of the digital era. Creativity principle also affords the process of humanization, because it goes hand in hand with the process of human development. In the theory of philosophical anthropology, creativity principle is parallel with the principle of subjectivity. The concept of subjectivity in philosophical anthropology is a concept that emphasizes the importance of human being in the totality of the selfhood. Humans are glorified and respected from all aspects as human being personally.

The theory of subjectivity and its subjectivity principle in the existentialism can be used to explain the core meaning of creativity principle. The main idea lying in the two principles is of the theory of human development. The principal idea of Soren Kierkegaard's and Jaen-Paul Sartre's existentialism, for example, is on the concept of "self-actualization". Individuality in the idea of the two existentialists primarily accentuates the idea of the selfhood. They stand against the idea of man that is universalistic. Man, in their view, is particular. Social system tends to immerse the selfhood under the general understanding of man.

Creativity principle also involves the process of decision making. Man is free to choose him/herself. One is free to shape one's own life according to what one will for him/herself. Briefly we may say that it is of a free will man is able to shape $\mathrm{him} / \mathrm{h}$ erself to be an authentic self. Creativity principle therefore is a principle where every person is able to obviate, in Sartre's words, quietism; state of apathetic or indifferent. Quietism is an attitude of accepting reality without doing any efforts to fight against oppressions. ${ }^{6}$

Digital technology offers the opportunity of reshaping the human civilization to be more egalitarian, democratic and humanitarian. Technological revolution has being transforming the systems in almost every field, from the centralized into decentralized system. In the political sphere, power is no longer centered on one or two hands. In the economic field, economic power is no longer centered on the giant companies. The hegemony of the capitalist has now been declined. In contrast, creative industries are growing up. Small and middle class industries are survived.

Digital technology transforms massively the economic system. We may say that this is the end economic system of the chimney era. Production system in the digital age is totally transformed from massive production to limited production. Alvin Toffler named the transformation as the era of demassification. ${ }^{7}$ Demassification is the process of breaking something standardized or homogeneous into elements that appeal to individual tastes or special interests. Society and social systems become less uniform. We may say that the digital age is that age of

${ }^{6}$ Jean-Paul Sartre. Existentialism and Humanism. London: Eyre Methuen LTD, 1973. P. $40-41$.

${ }^{7}$ Alvin Toffler. The Third Wave. New York: William Morrow and Company INC, 1980. P. 248. 
diversity. One-hand hegemony in the industrial age is replaced by the multi-hand of the economic networks.

One-hand control system in the era of chimney industry and in the ancient capitalism due to the technology used was expensive giant technology. On the contrary, the technology used in the digital age is cheap mini technology. Anyone has opportunity to own technological tools. Massive production system - large quantities of homogeneous production - in the chimney era is now replaced by assorted production system - large quantities of diverse production. With computerized technology, for example, creative industries can produce thousands of clothes of variant designs in a day. Computerized technology has been used up to home industries.

In the digital era many giants companies collapsed, whereas many small and middle class industries flourish. They are creative industries able to compete with the giants companies and also capable of complying the market demands. In the developing countries like Indonesia, for example, many giant textile companies go bankrupt because they are unable to compete with the new rising creative industries. They work effectively and are able to fulfill the demands of the market for fashionable products.

This characteristic of digital technology puts to end both the Freudian reality principle of the ancient capitalism and the performance principle. ${ }^{8}$ Both principles in the digital age are complemented by the principle of self-actualization. Massive production principle in the chimney era is now completed by creativity principle. The chimney era system is marked by dehumanization where the laborers are considered as robots able to be exploited.

In Marcuse's words, the employers are instrumentalized. They are considered as money-making machines for the capitalists. The employers are considered as assets able to be used for the benefit of the capitalists. Working in chimney era is seen as the aim of human life. The meaning of labor as a self-actualization is degraded merely as a process of self-fulfillment for the economic aspect. Meanwhile, working in the digital era is considered as a manifestation of the creative-self. One's capacities and potentials are totally explored.

This is a huge difference between the meaning of work in the chimney era and in the digital era. Work in the chimney era is defined as the purpose of human life. Humans live for work. However, work in the digital era is defined as a means for humans to actualize themselves. Life is not for work but working for life, because working is only a means for man's survival. It can be said that work is a means for humans to explore themselves. The exploration principle then replaces the exploitation principle of ancient capitalism. Working then is understood as a means of the self-actualization for living, not living for working for the sake of productivity.

We may briefly say that the creativity principle in the digital age lead the digitalized society to the system based on the self-actualization principle. It is the

\footnotetext{
${ }^{8}$ Franz Magnis-Suseno. Dari Mao ke Marcuse. P. 257.
} 
system that considers human being as human. Self-actualization is manifested through the process of developing one's own potentials totally. It is called a process of humanization. Humanization process is a process of accentuating human development to an actual self and to an authentic self. In the philosophical anthropology the actual self, for example from the idea of creative individuality of Hartley Burr Alexander, can only be achieved through decision making and through the process of self-choosing. ${ }^{9}$

The process of self-choosing is a process where man is aware of his/her own capacities. This process goes hand in hand with the feature of digitalized system. It is a system that glorifies freedom. Through freedom man is free to explore one's own self creatively. The authentic self is only achievable if one opens him or herself to form and to be shaped through ongoing self-exploring. This idea of authentic self can be compared to the idea of individuality and subjectivity in Soren Kierkegaard's existentialism. ${ }^{10}$ In the digital age everyone is required to be prolific or productive. Everyone is demanded to be more active of developing one's own self. It is the era man shape of him or herself to be a creator and producer, not only a consumer.

Digital era is the era where man is urged to be entrepreneurs; the one that creates jobs at least for him or herself. This is no longer the labor era. Creative industries in the digital age provides everyone opportunity to become a boss for him or herself. Man is no longer looking for jobs, but creating jobs. Hence creativity principle and self-actualization principle are very much needed. Society is shaped to be more creative and explorative. Shortly we may say that this is era where human transform from "exploited by" to "exploring for", because digital era is the era of networking.

\section{The Age of Partnership}

Marx's and Marcuse's criticism of the exploitative, repressive and slavery in the capitalist system gradually become irrelevant. The "boss-laborer" pattern of relation in the chimney era is now replaced by the "partnership" pattern in the digital era. Social relation in almost every aspect is marked by the networking system. We may take a look at an entrepreneur of coffee shop in London runs the culinary business through building a direct network and cooperation with coffee farmers in Brazil, clove farmers in Columbia, vanilla farmers in Africa and cashew farmers in Thailand.

Their business relationship is based on friendship and on trust. The pattern of the relation is not "boss-laborer or boss-farmer", but it is a partnership that is mutualistic and interdependent. The coffee shop entrepreneur is unable to run his business if the farmers do not supply any yield. On the contrary, the farmers

\footnotetext{
${ }^{9}$ Thomas M. Alexander. Hartley Burr Alexander: Humanistic Personalism and Pluralism. In The Pluralist, Vol. 3, No. 1, SPRING 2008. USA: University of Illinois Press, 2008. P. 89-127.

${ }^{10}$ See Robert L. Perkins -editor- in the International Kierkegaard Commentary. Two Ages: The Present Age and the Age of Revolution, a Literary Review Volume 14. Macon GA: Mercer University Press, 1984. Subtheme written by John W. Elrod: Passion, Reflection and Particularity. P. 1-2.
} 
automatically are collapsed if they there is no market buying their products. The relationship is consistent, imperishable and long-lasting when both parties jointly make a fair and egalitarian agreement without any repression.

Multi-polar relation provides more opportunities to everyone of knitting links to anyone and to any parties one will. This is an era where everyone is provided of many possibilities, choices and alternatives. On the other hand, bipolar system of the ancient capitalism is in decline. The hegemony of the giant distribution companies loss power. Digital society prefers a direct transactions in the pattern of "person to person" or "person to company". It is digital technology that makes it possible.

Multipolar system puts to an end the "master-slave" relation of the ancient capitalism. It is because networking system supported by information network shapes a new pattern of asymmetrical partnership. Partnership system requires creative and competent human resources. The main standard of this pattern is a mutual trust. For mutual trust is the fundamental formula of the partnership system, the principal demands for the economic actors are adequate competence and integrity.

Emphasizing on the competence and integrity opens the way to a more emancipative and egalitarian social system. Multipolar system provides opportunity to everyone to be able to escape from the exploitative system inherent in the ancient capitalism. It is in this system man is given multiple choices. One is free to choose with whom he/she is willing to work and to do business that is fairer and more just.

On the contrary, the unfair and the unjust system face the social punishment. Digital society has been transformed into a solider society. They are more heedful to the social issues. This society is a cohesive society. It is because digital society is backed up by a wide-global information network. The emergence of social media such as youtube, facebook, twitter, instragram, whatsapp and many others help to establish this cohesiveness, although at the same time it goes hand in hand with the ill-usages. This cohesiveness becomes the trigger of the emergence of massive and wide resistance to all sorts of unjust system. The plenteous society is no longer an asocial society. They have been transformed to be a hyper-social; a heedful and critical society.

This hyper-social society is a discursive society. They easily form an electronic community able to discuss various social problems through cyber media. ${ }^{11}$ They are wide interconnected. This is a world of hyperlink, where every group and communities unites all social issues into a single box and makes them a common problem and common solution. The monopoly on access to information which has been closed for a long time by capitalists is now opened to the society. Shortly, it is an era of transparency of information. It shapes the way society understands and view the social systems imposed to them. The resistance to any unjust and unfair systems comes from there. Digital society is a society that is not easy to be

${ }^{11}$ Alvin I. Goldman. Knowledge in a Social World. New York: Clarendon Press-Oxford, 1999. P. 166. 
subjugated and intimidated by any deceitful grand narratives of the capitalist system. Transparent systems applied in the digital society shape a world that is more egalitarian, humanitarian and solider.

It is humans who determine their own history and civilization. Culture, political systems and economics, knowledge and technology man create are the devices that make up their civilization. Freudian reality principle - civilization presupposes oppression - is not a predestination that cannot be changed, because human civilization is a process human determines itself creatively. Creativity principle - civilization presupposes creativity - is a principle where humans take choices and make decisions to become who they want to be. Digital technology provides that opportunity. It is a human masterpiece and a means for man to build a better civilization.

\section{References}

[1] Alexander ThM. Hartley Burr Alexander: Humanistic Personalism and Pluralism. The Pluralist. SPRING 2008; 3 (1). USA: University of Illinois Press; 2008.

[2] Goldman AI. Knowledge in a Social World. New York: Clarendon Press-Oxford; 1999.

[3] Marcuse H. Eros and Civilization: A Philosophical Inquiry into Freud. New York: Vintage Books; 1955.

[4] Marcuse H. One-Dimensional Man: Studies in the Ideology of Advanced Industrial Society. London: Routledge \& Kegan; 1964.

[5] Marx K. Capital: a Critique of Political Economy. Volume I. First Published in German in 1867 and English first edition in 1887. Moscow: Progress Publishers; 2015. (In Russian).

[6] Mirandola Giovanni Pico della. Oration on the Dignity of Man. Washington: Regnery Gateway; 1956.

[7] Perkins RL (ed.). The International Kierkegaard Commentary. Two Ages: The Present Age and the Age of Revolution. Literary Review. Volume 14. Macon GA: Mercer University Press; 1984.

[8] Sartre J-P. Existentialism and Humanism. London: Eyre Methuen LTD; 1973.

[9] Suseno FM. Dari Mao ke Marcuse. Jakarta: Penerbit PT Gramedia Pustaka Utama; 2013.

[10] Toffler A. The Third Wave. New York: William Morrow and Company INC; 1980.

\footnotetext{
About the authors:

Chernyak A.Z. - PhD in philosophy, associate Professor at the Department of Social Philosophy, RUDN University (e-mail: chernyak-az@rudn.ru).

Lemanto E. - Indonesian student studying and completing doctoral program at the Department of Social Philosophy, RUDN University (e-mail: lemanto-a@rudn.ru).
} 


\title{
Цифровое общество и многомерный человек (Новая постановка вопроса «Одномерного человека» Маркузе)
}

\author{
А.3. Черняк, Э. Леманто \\ Российский университет дружбы народов \\ ул. Миклухо-Маклая, 6, Москва, Российская Федераџия, 117198
}

\begin{abstract}
Одной из основных проблем социальной философии является технологическая революция и ее влияние на социальные системы. Критические взгляды на эти системы со стороны социальных философов отталкиваются от социальных проблем своего времени. Ключевым критическим тезисом Карла Маркса в его работе Das Capital является бедность, вызванная системой капитализма. Для него капитализм порождает только негативные социальные последствия, такие как рабство, угнетение, эксплуатация и обнищание. Герберт Маркузе указывает на ту же проблему, но выбирает иной угол зрения. Маркузе критикует общество изобилия. В «Одномерном человеке» Маркузе выступил с резкой критикой индустриального общества. Индустриальное общество, с его точки зрения, характеризуется изобилием и избытком, но это общество все еще угнетено новым типом рабства, называемым добровольным рабством. В итоге можно резюмировать: оба философа построили критику индустриального общества, но при этом стояли на разных позициях. Критика Маркса - это критика общества недостатка, голодного и неполноценного, критика Маркузе - критика сытого, обильного и избыточного общества. Цель этой статьи - показать, как одномерный человек Маркузе заканчивается в цифровую эпоху.

Ключевые слова: одномерный человек, многомерный человек, дегуманизация, эксплуатация, инструментализация, индустриальное общество, цифровое общество, капитализм
\end{abstract}

\section{История статьи:}

Статья поступила 06.08.2019

Статья принята к публикации 23.12.2019

Для цитирования: Черняк А.З., Леманто Э. Цифровое общество и многомерный человек (Новая постановка вопроса «Одномерного человека» // Вестник Российского университета дружбы народов. Серия: Философия. 2020. Т. 24. No 2. С. 286-296. DOI: 10.22363/2313-2302-2020-24-2-286-296

\section{Сведения об авторах:}

Черняк A.3. - кандидат философских наук, доцент кафедры социальной философии Российского университета дружбы народов (e-mail: e-mail: chernyak-az@rudn.ru).

Леманто Э. - докторант кафедры социальной философии Российского университета дружбы народов (e-mail: lemanto-a@rudn.ru). 